Bangladesh Journal of Anatomy July 2009, Vol. 7 No. 2 pp. 101-104

\title{
Stature Estimation Using Head Measurements in Bangladeshi Garo Adult Females
}

\author{
Zakia Akhter ${ }^{1}$, Jahan Ara Begum ${ }^{2}$, Mst. Laila Anjuman Banu ${ }^{3}$, Md Mahbubul Alam, Samira \\ Hossain ${ }^{5}$, Nahid Farhana Amin ${ }^{6}$, Md. Mesbah Uddin ${ }^{7}$, Quazi Samsunnahar Yasmin ${ }^{8}$
}

\begin{abstract}
Context: Stature is the height of the person in the upright posture. It is an important measure of physical identity. Interrelationships among different body measurements may be used to estimate one from another in case of missing body parts. As any part of the human skeleton can be found as the evidences, there arise a need to investigate whether there is any possible significant correlation between stature and any parts in human body. Garos, our study subject living in Bangladesh are usually recognized as an ethnic community, they have a separate identity and their physical appearance is distinctive to some extent. The present study was conducted with the intention to establish ethnic specific anthropometric data for the Bangladeshi Garo tribal populations and also to determine whether there is any correlation between the measured values of the stature and the physically measured cranial variables, to estimate (using respective multiplication factor) the stature from the physically derived cranial measurements and to assess the effectiveness of such estimation.
\end{abstract}

Study design: The study was an observational, cross-sectional and descriptive in nature with some analytical components.

Study settings and study period: The study was carried out in Bangabandhu Sheikh Mujib Medical University (BSMMU), Dhaka, during the session of January to December 2008.

Selections of the subjects: A total number of one hundred Garo female subjects were included from Dhaka city and Mymensingh district.

Methods: Cranial dimension such as head circumference, head length and stature were measured using a measuring tape, spreading caliper, steel plate and steel tape.

Results: Head circumference showed significant positive correlation with stature but head length did not reach statistically significant level with stature. No significant difference was found between the 'measured' and 'estimated' stature for head circumference and head length.

Key words: Anthropometry, stature, correlation, head circumference, head length

\section{Introduction:}

The anthropometry is the science of measuring the human body and its parts and craniofacial

1. Asstt. Professor, Z.H. Sikder Women's Medical College, Dhaka

2. Professor, Department of Anatomy, BSMMU, Dhaka

3. Associate Professor, Department of Anatomy, BSMMU, Dhaka

4. DLO Course, OSD (DGHS), Deputed on BSMMU, Dhaka

5. Asstt. Professor, Green Life Medical College, Dhaka

6. Asstt. Professor, Anwer Khan Modern Medical College, Dhaka

7. Asstt. Professor, Kumudini Women's Medical College, Tangail

8. Asstt. Professor, Dhaka Community Medical College, Dhaka Correspondence: Dr. Zakia Akhter anthropometry, involves measurement of the skull and face ${ }^{1}$. Stature or body height is one of the important and useful anthropometric parameter that determines the physical identity of an individual ${ }^{3}$. Anthropometric measurements of different body parts are used in differentiating between ethnic groups, in identifying missing persons and suspects, in treating craniofacial deformities etc. Standards based on ethnic or racial data are desirable because these standards reflect the potentially different patterns of craniofacial growth resulting from racial, ethnic and sexual difference ${ }^{3}$. In Bangladesh, studies on craniofacial measurements are limited to mostly on caste and community and rarely in tribal population. Garos, 
the tribal population of our study subject living in Bangladesh are usually recognized as an ethnic community, they have a separate identity. They mostly live in Mymensingh, Netrokona, Tangail, Sylhet and Sunamgonj districts of our country. They are an ethnic group of 'Tibbeti Borman', belonging to the Mongolian human race. They are different from any other tribal community and of course not consistent with the tradition of mainstream Bangladeshi common people ${ }^{4}$.

\section{Methods:}

The study was basically an observational, crosssectional and descriptive in nature. There was also another analytical procedure used to compare two corresponding sets of data ('measured' and 'estimated' values) for some variables. The study was done on one hundreds Christian Garo adult females, 25 to 45 years of age.

The stature was taken by using steel plate and steel tape. The subject stood with her heel together and her back as straight as possible so that her heels, buttocks, shoulders touched the wall. The arms were hung freely by the sides with the palm facing the thighs. A steel plate was placed against the head and wall to determine maximum height on the wall and this was marked ${ }^{5}$. The height was then measured in centimeters from the floor to the mark on the wall with steel tape. The head circumference was measured by using flexible measuring tape. At first the subject was allowed to sit on the chair with head in the anatomical position. The head circumference was obtained by placing the flexible measuring tape on the occipital protuberance behind and supraorbital ridge in front ${ }^{7}$. Then the head length was measured by the spreading caliper from glabella to inion ${ }^{6}$. Conventional technique keeps caliper along a sagittal midline.

\section{Calculations of multiplication factors}

Each 'multiplication factor' is the ratio of the stature to the respective cranial variables. Mean multiplication factor was then calculated for each cranial variables. This means multiplication factor was used for estimating the stature from those particular cranial variables.

Multiplication factor (M.F.) of each cranial variable was calculated using following formulae:

$$
\text { M.F }=\frac{\text { Stature }}{\text { Head circumference or head length }}
$$

Results:

The mean values of the stature, head circumference and head length were found. The mean $( \pm$ SD) of the stature, head circumference and head length were $152.79 \pm 5.62 \mathrm{~cm} ., 51.56 \pm 1.49 \mathrm{~cm}$ and 17.49 $\pm 0.58 \mathrm{~cm}$ (Table-I). Here head circumference showed significant positive correlation with stature but head length did not reach statistically significant level. The mean multiplication factors $( \pm S D)$ for estimating the stature from head circumference was found as $2.97 \pm 0.12$ and from head length was found as $8.75 \pm 0.45$ (Table-I). No significant difference was found between the 'measured' and 'estimated' stature for head circumference and head length (Table-II, Fig.-1,2).

Table-I

Stature and head circumference, head length obtained through direct physical procedures

\begin{tabular}{lccc}
\hline Variables & $\begin{array}{c}\text { Physical } \\
\text { measurement } \\
\text { Range }(\mathrm{cm})\end{array}$ & $\begin{array}{c}\text { Mean multiplication } \\
\text { factor } \pm \text { SD } \\
\text { Mean }(\mathrm{cm}) \pm \text { SD }\end{array}$ & $\begin{array}{c}\text { Significance of } \\
\text { correlation with stature }\end{array}$ \\
\hline Stature & $136.00-168.50$ & $152.79 \pm 5.62$ & $2.97 \pm 0.12$ \\
Head circumference & $49.00-55.00$ & $51.56 \pm 1.44$ & $p=0.005(\mathrm{~S})$ \\
Head length & & & $8.75 \pm 0.45$ \\
& $15.80-18.50$ & $17.49 \pm 0.58$ & $p=0.774(\mathrm{NS})$ \\
\hline
\end{tabular}

n : 100 for each variable.

S : Significant at $5 \%$ level in regression analysis.

NS : Non-significant 
Bangladesh J. Anat. 2009; 7(2) : 101-104

Table-II

Comparison between the 'measured' stature and the stature 'estimated' from head circumference and head length

\begin{tabular}{lccc}
\hline Cranial variable & $\begin{array}{c}\text { Measured stature } \\
\text { Mean } \pm \text { SD }\end{array}$ & $\begin{array}{c}\text { Estimated stature* } \\
\text { Mean } \pm \text { SD }\end{array}$ & $\begin{array}{c}\text { Significance of } \\
\text { difference } \dagger\end{array}$ \\
\hline Head circumference & $152.79 \pm 5.62$ & $153.12 \pm 4.30$ & $\mathrm{p}=0.586(\mathrm{NS})$ \\
Head length & $152.79 \pm 5.62$ & $152.91 \pm 5.11$ & $\mathrm{p}=0.875(\mathrm{NS})$ \\
\hline
\end{tabular}

* The mean 'estimated' stature against head circumference and head length was obtained by multiplying each individual value $(n=100)$ for the variable by the respective mean multiplication factor (as shown in Table-I). Then the mean of 100 values was calculated for that variable.

† Significance of difference was tested using the paired't' test setting the level of significance at $p<0.05$.

NS: Non-significant

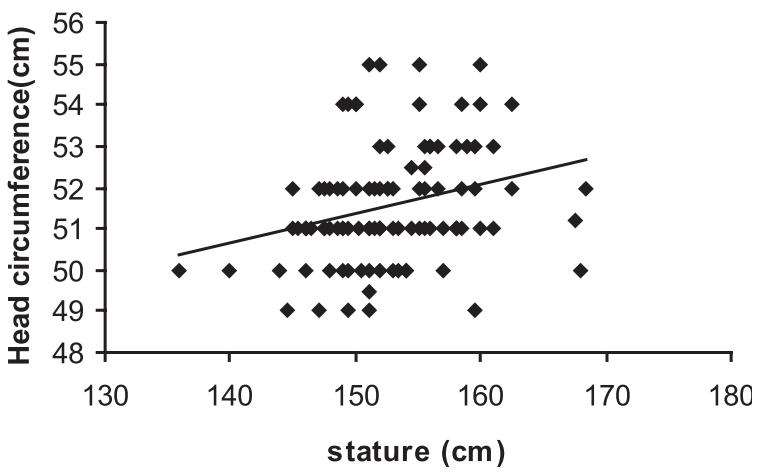

Fig.-1: Scatter diagram with regression analysis showing significant positive correlation between the stature and the head circumference ( $r=0.278$ and $p=0.005)$.

\section{Discussion:}

The present anthropometric study was carried out among Christian Garo adult females with a view to measure the stature, the head circumference and the head length. It also looked for any correlation between stature and head circumference, stature and head length. Estimation of stature was made from head circumference and head length using multiplication factors and effectiveness of the estimations was tested. Garo tribe belongs to the Mongoloid race, some similarities are expected to exist with other ethnic groups of the Mongoloid race and some dissimilarity may be expected with other races. In the present study, the mean stature, head circumference, head length were found as 152.79 $\mathrm{cm}, 51.56 \mathrm{~cm}$ and $17.49 \mathrm{~cm}$ which are somewhat close to the mean values of the Philippina ${ }^{8}$,

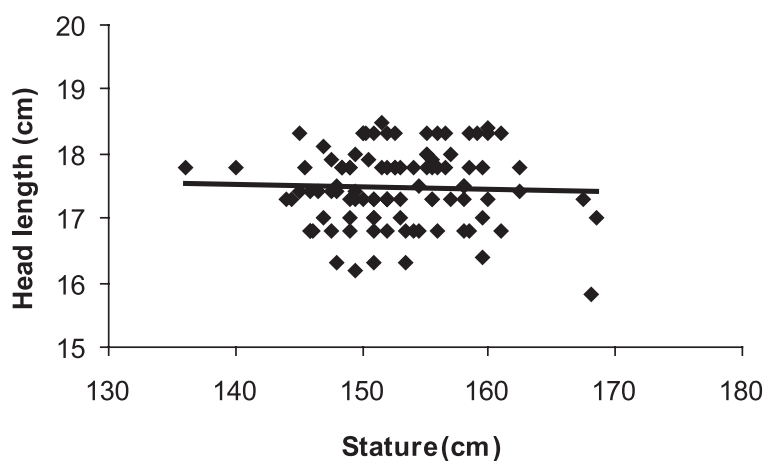

Fig.-2: Scatter diagram with regression analysis showing non-significant negative correlation between the stature and the head length ( $r=-0.029$ and $p=0.774$ ).

Japanese $^{8}$, Chinese8, Manchu ${ }^{10}$ and Gurung females of the $\mathrm{Nepal}^{7}$ but in some other ethnic group such as Mysorean ${ }^{6}$, Santhal ${ }^{11}$, Onge ${ }^{9}$, Khond ${ }^{12}$, British Protestant ${ }^{13}$, Jew ${ }^{13}$, Somali ${ }^{14}$ they show variation in stature. Again in case of head circumference and head length there also some similarity was found in case of some Mongolian group and dissimilarity was found in other ethnic group. In our study, the stature was found to have significant positive correlation with head circumferences but the head length did not reach statistically significant level. The mean multiplication factor of the head circumference and head length stood as $2.97 \pm 0.12$ and $8.75 \pm 0.45$. Multiplying these multiplication factors with the head circumference and head length of individual there found estimated stature. No significant difference was found between 
the 'measured' and 'estimated' stature for head circumference and head length. This indicates the effectiveness of the corresponding multiplication factor in this estimation. It also be noted that though there was no significant correlation found between stature and head length but the stature estimated from the head length (by using multiplication factor) did not differ significantly from the measured stature. This indicates that further investigation is necessary, using larger samples, to come to definitive conclusions in this regard.

\section{Conclusion:}

Probably, this is the first anthropometric study that carried out on the Garo tribal population of Bangladesh and the result of the present study will provide some baseline information regarding stature and two cranial measurements of this particular population. As the cranial measurements and stature facilitate identification of missing person and helps in diagnosis and treatment of some anomalies, so knowledge of normal value for these regions produces the best aesthetic and functional results. These values may also be helpful to the anatomists for normatic references. Significant correlations, detected in the study between some of the measurements can be utilized in the determination of proper multiplication factors to be useful in estimating one measurement from another.

\section{References:}

1. Craniofacial anthropometry [online]. Availablefrom:http://en.wikipedia.org/wiki/ Craniofacial_anthropometry

2. Jibonkumar, Lilinchandra, 2006. Estimation of stature using different facial measurements among the Kabui Naga of Imphal Valley, Manipur. Anthropologist, 8 (1). Available from:http://www.answers.com].

3. Evereklioglu, C. et al., 2002.Craniofacial anthropometry in a Turkish population. The Clef t Palate-Craniofacial Journal [online], 38(3). Available from:http://cpcj.allenpress.com

4. Das, T., Islam, S.M.H.Z., 2005. Psychosocial dimensions of ethnicity: the situation of Garo community in Bangladesh. Asian Affairs [online], 7(3). Available from: http:// www.cdrb.org/journal/2005/3/3
5. Brown, J. K., Feng, J., Knapp, T. R., 2002. Is self-reported height or arm span a more accurate alternative measure of height

6. Kalia, S., Shetty, S., Patil, K., Mahima, V., 2008. Stature estimation using odontometry and skull anthropometry. Indian Journal of Dental Research [online], 19(2). Available from: http://www.ijdr.in/article.asp? Issn =0970

7. Lobo, S.W., Chandrashekhar, T.S., Kumar,S., 2005. Cephalic index of Gurung community of Nepal- an anthropometric study. Kathmandu university medical journal [online], 3(3). Available from: http://lib.bioinfo.pl/pmid:18650589

8. Human height [online]. Available from: http:// www.answer.com/topic

9. Panday, A.K., 2006. Cephalofacial variation among Onges. Anthropologist [online],8(4). Available from: http://www.krepublishers.com/02

10. Hirohide, K., 1995.A study on anthropometric measurement of head and face and morphology of dental arch on Manchu tribe. The journal of the Kyushu Dental Society [online], 51(2). Available from: http://ci.nii.ac.jp/ cinil/Servlet/Quot DISP.

11. Ghosh, S., Malik, S.L., 2007. Sex difference in body size and shape among Santhal of West Bengal. Anthropologist [online], 9(2). Available from: http://www.krepublishers.com/ 02-Journals/T-.

12. Rao, V.L.N., Rao, D., Rao, S., Busi, B.R., 2005. Patterns of growth and physiological variables among Khond tribal population of Visakhapatnam district, Andhra Pradesh. Anthropologist [online], 7(4). Available from: http:// www. Krepublishers.com/02-journal

13. Rife, D.C., 1949. Comparison of Stature, Weight and head measurements among Catholic, Protestant and Jewish Student, Paper presented at the meeting of the American Society of Human Genetics in New York. Available from: http:// kb.oju.edu/dspacc/ bitstream

14. Lucia, E., Leema, F., Tesfaye, F., Demisse, F., Ismail, S., 2002. The uses of arm span measurement to assess the multinational status of adults in four Ethiopian ethnic groups. European Journal of Clinical Nutrition [online], 56 (2). Available from: http://www.nature.com/ ejon/journal. 